\title{
Application of the Preliminary Geosite Assessment Model (GAM): The Case of the Bela Crkva Municipality (Vojvodina, North Serbia)
}

\author{
Jovana Boškov ${ }^{*}$, Stefan KotrlaA, Mlađen Jovanović ${ }^{A}$, Nemanja Tomić ${ }^{A}$, Tin LukićA, Ivan Rvović ${ }^{A}$ \\ Received: June 17, 2015 | Revised: August 27, 2015 | Accepted: September 1, 2015
}

\begin{abstract}
Bela Crkva municipality is located in the northeastern part of Serbia, in the southeast of the Autonomous Province of Vojvodina. This Municipality has a high concentration of geosites which are of a great importance, and providing a good basis for the geotourism developement in this area. This paper proposes an inventory of geosites in the Bela Crkva municipality. One of the aims of the paper is to evaluate different values of geosites using preliminary Geosite Assessment Model (GAM) in order to determine whether this area has the potential for geotourism development.
\end{abstract}

Key words: geosites, geoheritage, geotourism, evaluation, Bela Crkva, Vojvodina, Serbia

\section{Introduction}

As a result of contemporary tourism trends there is an appearance of new, special forms of tourism that differ from mass tourism primarily because the center of their interest is to satisfy the needs of tourists and locals, with heightened environmental concerns. One of these special forms of tourism is geotourism, based on geodiversity and geoheritage. Geodiversity can be defined as natural range of rocks, minerals, fossils, geomorphological forms and processes, and soil features; it includes their assemblages, relationships, properties and systems (Gray, 2004). Geoheritage usually includes all geological, geomorphological, pedological and distinct archaeological values created during the formation of the Earth's crust, its morphological shaping and interdependence of nature and human culture, which thanks to their great scientific and cultural importance have to be under special concern of all social factors (Đurović, Mijović, 2006). Geoheritage includes particular examples or elements of geodiversity which are of great importance for humans, regarding to the use for various purposes (except for the exploitation of such resources), whithout diminishing their intrinsic or environmental values (Sharples, 2002). Another term that is closely related to the previous is geoconservation which includes the preservation of rocks, fossils, minerals, relief forms and museum settings (www.geoconservation.com). Hose (2005) also claims that geoconservation measures joined with tourism promotion are key geotourism elements. The same author has provided a comprehensive definition of geotourism as "The provision of interpretative and service facilities for geosites and geomorphosites and their encompassing topography, together with their associated in-situ and ex-situ artefacts, to constituency-build for their conservation by generating appreciation, learning and research by and for current and future generations" (Hose, 2012).

Among many potential geotourism destinations in Serbia, is Bela Crkva, i.e. the entire Municipality with a number of individual sites such as the Banat Sands, Mali pesak, rivers Nera and Karaš with their fossil meanders, Danube with the Danube-Tisa-Danube (DTD) canal, Labudovo okno etc. In addition to the natural values that are the basis for geotourism development, there are plenty of anthropogenic values that

\footnotetext{
A University of Novi Sad, Faculty of Science, Department of Geography, Tourism and Hotel Management, Trg Dositeja Obradovića 3, 21000 Novi Sad, Serbia

Corresponding author: Jovana Boškov, e-mail: boskovjovana@gmail.com
} 
complement the offer of geotourism. However, despite its significant geopotential, developed destinations for this type of tourism are in a low extent present in Serbia (Devil's Town, Resavska cave, Ceremošnja cave, Mramorna cave and other caves). In order to promote geotourism in some area it is necessary to assess the current status and value of all geosites that are present in that area, which can be achieved by proper tourist evaluation. GAM model should help in assessing the potential for the geotourism development, as well as to assist the planning process and sustainable management of geosites.

\section{Study area}

Bela Crkva municipality is located in the northeastern part of Serbia, in the southeast of the Autonomous Province of Vojvodina. It covers an area of 353 $\mathrm{km}^{2}$ and territorially belongs to the South Banat district. On the north it borders with the municipalities of Kovin and Vršac, on the east it borders with the Republic of Romania, while on the south it comes out on the left bank of the Danube. The Municipality is characterized by a relatively good tourist position. The distance from Belgrade, the capital and most important city center is approximately $95 \mathrm{~km}$. The distance of other centers is: Vršac (37 km), Kovin (47 km),
Požarevac (5o km), Smederevo (6o km), Pančevo (8o km) (Boškov, 2014b).

Tourist position of the Municipality is also adequate regarding to complementary tourist sites, such as Special Nature Reserve "Deliblato Sands" National park "Iron Gate", the remains of old fortresses in Ram, Smederevo, Vršac, Kovin, as well as numerous hunting and fishing areas.

Over the border crossing Kaluđerovo, Bela Crkva is connected with border villages in Republic of Romania. The distance from Timisoara (Romania) is approximately $110 \mathrm{~km}$. In the vicinity of the Municipality there are several protected natural areas: $\mathrm{Na}$ ture Park "Iron Gate" (Parcul Natural "Portia de Fier”), National Park "Gorge Nera-Beusnica” (Parcul Naţional "Cheile Nerei- Beuşniţa”), National Park "Semenik-Gorge Karaš” (Parcul Naţional "SemenicCheile Căraşului”), National Park "Domogled-Černa Valley" (Parcul Naţional "Domogled-Valea Cernei”) etc (Boškov, 2014a). The Bela Crkva municipality has a high concentration of geosites which are of great scientific, educational, aesthetic and touristic importance (Boškov, 2014b). These values are the result of a complex geological structure and geomorphological processes that took place in this area, during the Earth's history. On the territory of the Municipality there are numerous natural values, and some of them

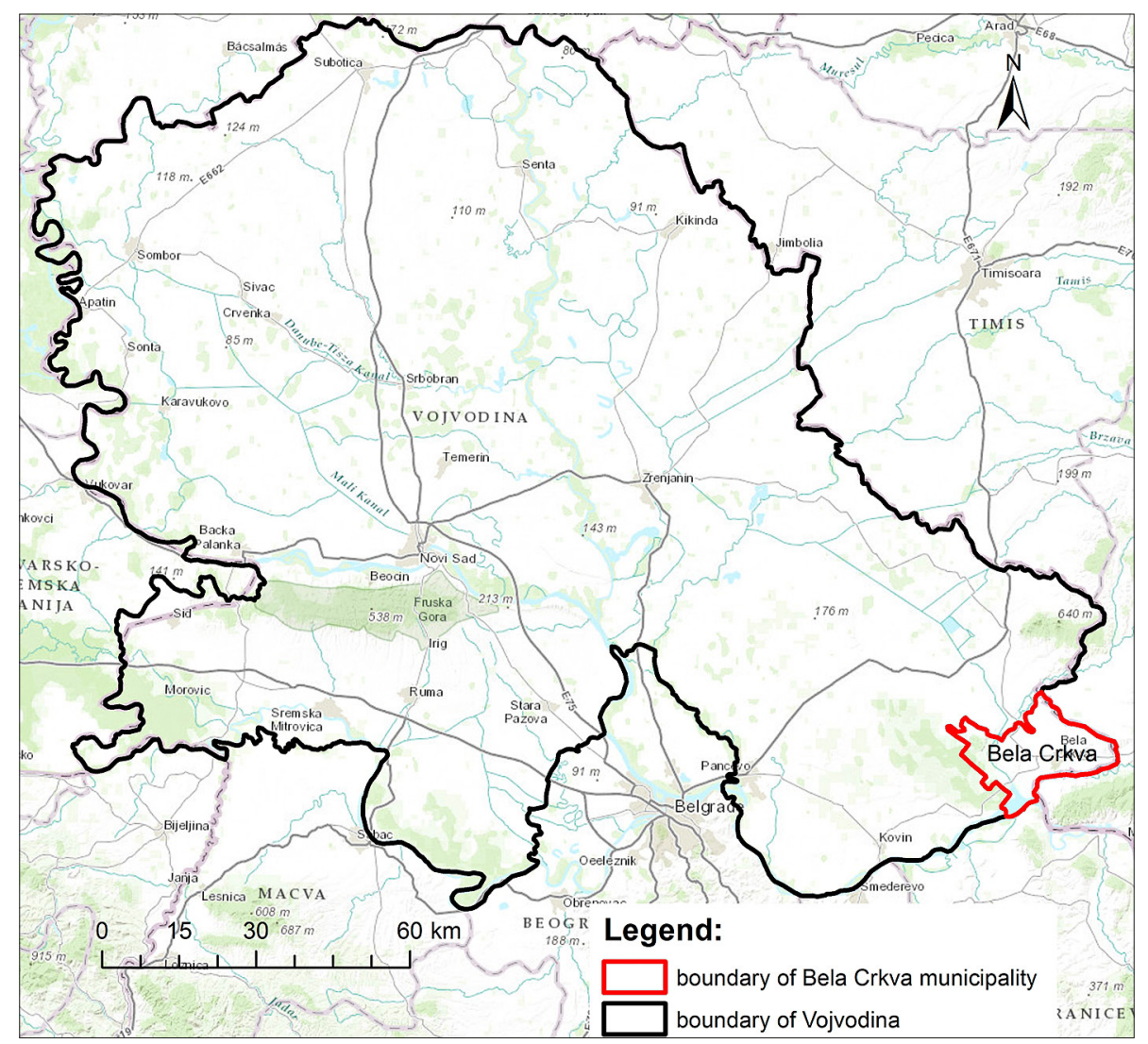

Figure 1. Location of Bela Crkva municipality in the Autonomous Province of Vojvodina (North Serbia) 
are protected. Loess plateu Dumača is part of Special Nature Reserve "Deliblato Sands", Labudovo okno is protected as a Ramsar site, and the protection process of the Landscape of exceptional features "KarašNera" as a protected area of II category with total area of 1,541.27 ha is currently in progress (Provincial Institute for Nature Conservation, 2011).

Furthermore, there is a big number of anthropogenic values, such as important archaeological sites. High concentration of geoheritage sites provides a good prerequisite for geotourism development, but these sites may also be used as additional attractions to other forms of tourism.

\section{Methodology}

The evaluation of geosites has been developing since the 1990s. Numerous papers were written concerning the evaluation of scientific, aesthetic and other values of geosites (e.g. Pralong 2005; Pereira, et al. 2007; Reynard, et al. 2007; Tomić, 2011; Vujičić, et al., 2011; Tomić, Božić, 2014; Vasiljević, at al., 2014; Petrović, et al., 2013; Hrnjak, et al., 2013; Lukić et al., 2013).

In this paper, the preliminary geosite assessment model (GAM), created by Vujičić et al. (2011) was used. This model actually shows the evaluation of geosites which should assist the sustainable management and planning proces as well as determining the potential for geotourism development.

Basically, the GAM model consists of two components and for this opportunity it will be written in a modified form of an equation (Hrnjak, et al., 2013):।

$G A M=M V+A V$

where, MV are the Main Values and AV represent Additional Values, whereby both values are used for the quantitative assessment of geosites. As each of the previous two values consists of the sum of more subvalues, this can be written using two equations:

$M V=V S E+V S A+V P r$

$A V=V F n+V T r$

where, VSE represents Scientific/Educational Values, VSA Landscape/Aesthetic Values, VPr are Values of the Protection/Conservation, VFn are Functional Values and VTr are Tourist Values.

According to the original GAM definition the equations (2) and (3) can be written as follows:

$M V=V S E+V S A+V P r \equiv \sum_{i=1}^{12} S I M V_{i}$,

where $0 \leq S I M V i \leq 1$
$A V=V F n+V \operatorname{Tr} \equiv \sum_{i=1}^{15} S I A V_{i}$,

where $0 \leq S I A V i \leq 1$

where, SIMV represents 12 subindicators within MV (Main Values) and SIAV represents 15 subindicators within the AV (Added Values), all as a basic assessment of the lowest rank for the evaluation of geosites. As it can be seen from equations (1) - (5), total assessment of geosites is obtained as the sum of all subindicators.

The list of all subindicators and the method of determining their values can be found in the original work of Vujičić et al. (2011).

As previously stated, in total sum there are 12 subindicators of Main Values, and 15 subindicators of Additional Values. All these subindicators were graded from o to 1 , for each proposed geosite separately. Based on the results of the assessment, a matrix of Main and Additional Values can be created, where these values are presented via $\mathrm{X}$ and $\mathrm{Y}$ axes respectively. The matrix is divided into nine fields (zones) that are indicated by $Z(i, j)(i, j=1,2,3)$ based on the grade they received in the previous evaluation process. Major gridlines that create fields, for $\mathrm{X}$ axe have value of 4 and for $\mathrm{Y}$ axe of 5 units (Vujičić, et al., 2011).

For example, geosites that fit in cell $Z_{31}$ and $Z_{32}$ have high scientific, aesthetic and protection values, but low developed tourist and functional sector. Thanks to these indicators, geosite managers now know that they need to better promote, plan and enhance these assets, while not degrading the first one. On the other side, geosites that fit in $Z_{11}$ and $Z_{12}$ cell have low main values and also low additional values. In this case there are two possible plans of action: the first one is that the geosite has no main values which resulted in also lower additional values; the second scenario is where the geosite is not fully researched and because of that is not protected, which implies that there is no need for additional values. Geosites that fit in $Z_{33}$ and $Z_{23}$ have high ratings in main and additional values. On these sites managers should measure the impact of tourism and threats; a solution for this problem is the constant monitoring of proposed subindicators (Vujičić, et al., 2011).

\section{The proposal of geosites inventory in the Bela Crkva municipality}

Bela Crkva municipality is characterized by great variety of geodiversity. The main elements of geodiversity are parts of the Banat Sands, former flows of Nera and Karas rivers, loess profiles etc. Considering that the area of Bela Crkva municipality consists of several 
Table 1. List of proposed geosites in Bela Crkva municipality and their description

\begin{tabular}{|l|l|l|}
\hline Designation & Name of proposed geosite & Description \\
\hline$G_{1}$ & Dumača loess plateau & $\begin{array}{l}\text { Geomorphological formation, part of Banat loess plateau with numerous dry } \\
\text { valleys and profiles.It is located in the western part of Bela Crkva municipality } \\
\text { (Hrnjak et al., 2013; Lukić et al., 2013). }\end{array}$ \\
\hline$G_{2}$ & $\begin{array}{l}\text { Loess profiles near Dupljaja } \\
\text { village }\end{array}$ & $\begin{array}{l}\text { Geologicalandgeomorphologicalformation. Represents unique archive of } \\
\text { paleoclimatic and paleoecological changes. }\end{array}$ \\
\hline$G_{3}$ & Mali pesak & $\begin{array}{l}\text { This morphological entity was separated from the Banat Sands by the valley of } \\
\text { the Karaš river. Its main characteristics are dunes and inter-dune depressions } \\
\text { (Bukurov, 1954). }\end{array}$ \\
\hline$G_{4}$ & $\begin{array}{l}\text { Fossil meanders of the } \\
\text { Karaš river }\end{array}$ & $\begin{array}{l}\text { Remains of the former riverbed of Karaš river, incurred by accumulative and } \\
\text { erosive force of water. }\end{array}$ \\
\hline$G_{5}$ & $\begin{array}{l}\text { Fossil meanders of the Nera } \\
\text { river }\end{array}$ & $\begin{array}{l}\text { Remains of the former riverbed of Nera river, incurred by accumulative and } \\
\text { erosive force of water. }\end{array}$ \\
\hline$G_{6}$ & Ramsar site Labudovo okno & $\begin{array}{l}\text { Part of the Special Nature Reserve "Deliblato Sands". Encompasses the coastlines } \\
\text { of Danube and Nera rivers, the river islands of Žilava, Čibuklija and Zavojska, } \\
\text { the flooded meanders of the Karaš rive and the mouth of the Nera river (www. } \\
\text { ramsar.org). }\end{array}$ \\
\hline
\end{tabular}

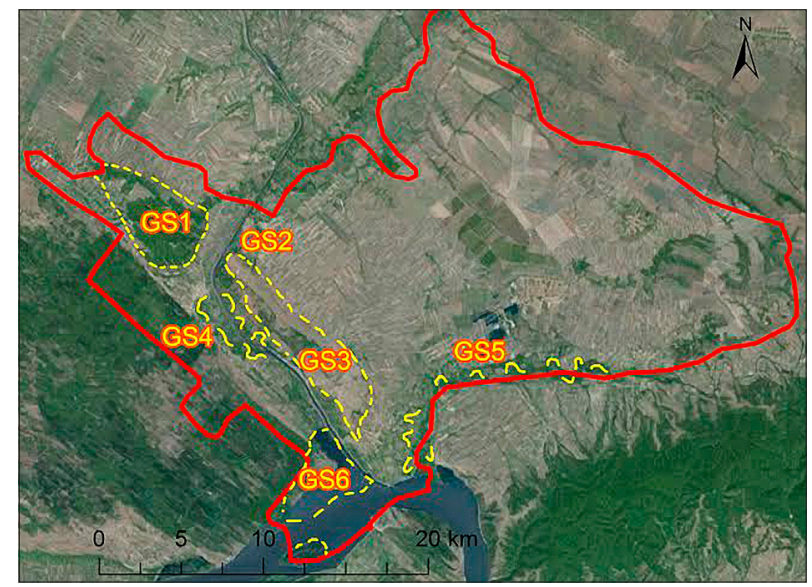

Figure 2. Location of proposed geosites in Bela Crkva municipality

Source: GoogleEarth; modified according to Boškov, 2014a

different geological and geomorphological objects, an inventory of geosites is proposed (Table 1).

Figure 2 shows the spatial distribution of geosites in Bela Crkva municipality. Most of the geosites are concentrated in the southwestern and western parts of the Municipality.

However, before any planning in potential geotourism destinations, accurate assessment of the condition and values of all geosites is necessary, which can be achieved by proper tourist evaluation.

\section{Results}

For each of the seven proposed geosites (GS1-GS7) 12 subindicators of main values (MV) and 15 subindicators of additional values (AV) are evaluated. As already mentioned, the GAM model was used for the evaluation of each proposed geosite separately. In order to elucidate the use of GAM, the method will be described in more detail by presenting its application on the Dumača loess plateau, designated as GS1.

\section{Scientific/Educational value (VSE)}

Within this group, subindicator rarity was valued with grade 0.25 for the reason that Dumača loess plateu represents rarity at the regional level. For subindicator representativeness, this site was rated with grade 0.75 , because it is a representative example of certain geomorphological processes. It has a high level of appropriate characteristics, stemming from its quality and general characteristics. As scientific papers related to this geosite are present only in regional publications, subindicator knowledge on geoscientific issues was evaluated with grade 0.5. Subindicator level of interpretation, was also graded with 0.5 because the proposed geosite represents a solid example to show geological and geomorphological processes, which, however, are not easily explainable to a wider audience, and the level of scientific knowledge is relatively low.

\section{Scenic/Aesthetic value (VSA)}

There is one viewpoint that is located less than one kilometer far from the proposed geosite, so the indicator viewpoints was evaluated with grade 0.25 . The altitude of the plateau is 251 meters at the Zagajica hills. The Dumača loess plateau is shaped as a very elongated isosceles triangle whose length is $14,5 \mathrm{~km}$ (Lukić, 2010). The surface is large, and for this subindicator the biggest grade (1) was given. Subindicator surrounding landscape and nature was evaluated with grade 0.75 due to the high level of nature quality, as well as the absence of negative anthropogenic influence. It perfectly fits into the natural environment, and for the indicator environmental fitting of sites it recorded a maximum value of 1 . 

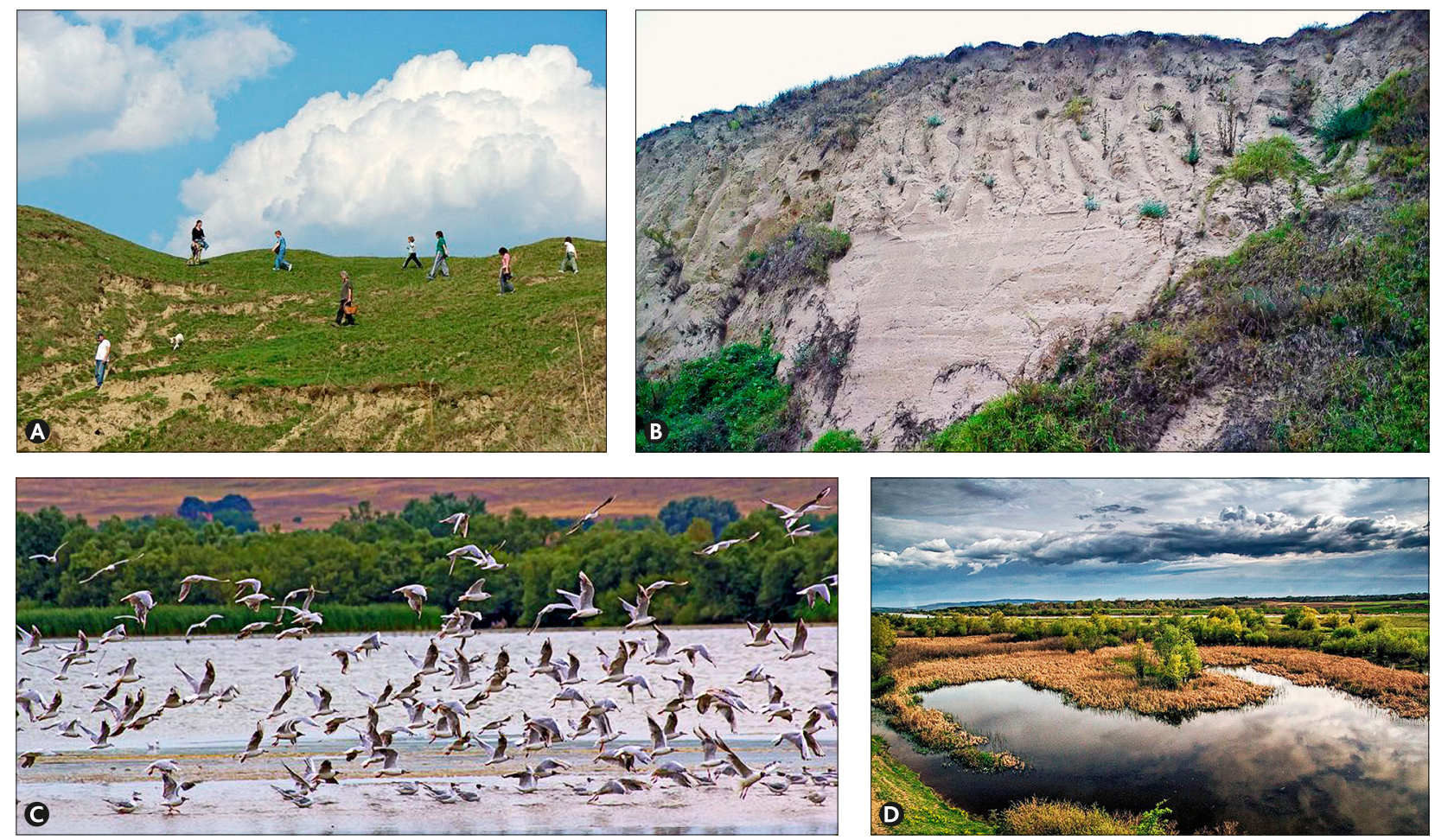

Figure 3. A - Mali pesak, B - Loess profiles near Dupljaja village, C - Labudovo okno, D - fossil meander of the Karaš river (photo by: Milan Belobabić)

\section{Protection (VPr)}

For the subindicator current condition, this geosite received the highest grade (1) because it is not degraded. As it is part of the Special Nature Reserve "Deliblato Sands" for parameter protection level it was evaluated with grade 0.75 . Vulnerability of this potential geosite reflects on a medium level, because damage to this area can be caused by natural processes as well as human activities. For this subindicator grade 0.5 was given. Suitable number of visitors is more than 50 at the same time, compared to the large surface area, so this subindicator was graded with 1 .

Adding up the grades for all of the 12 subindicators within the group of main values, it can be concluded that the total grade for this group of values is 8.25 .

\section{Functional value (VFn)}

Dumača loess plateau can be approached only by bicycle or by foot, so the accessibility was evaluated with grade 0.5. As it is located within the Special Nature Reserve, a number of additional natural values is relatively high, so the score for this subindicator is 0.75. Parameter additional anthropogenic values can be evaluated with grade 0.25 because there is an important archaeological site in the vicinity. The main emissive centers, Belgrade and Pančevo are located between 50 and $100 \mathrm{~km}$ far from this geosite, and a little further is Novi Sad. For this reason the vicinity of the emissive centers reaches a value of 0.25 . Regional road R-115 passes within a radius which is less than
$20 \mathrm{~km}$, that is why subindicator vicinity of important road network has a rating of 0.5 . Absence of gas stations, parking lots, mechanic shops etc. is the reason why subindicator additional functional values was rated with o.

\section{Touristic value (VTr)}

Within a group of touristic values the most of subindicators were evaluated with o, because in this area geotourism is practically not developped. Subindicators evaluated with grade o are: promotion, organized visits, vicinity of visitors center, interpretive panels, number of visitors, tour guide service. Subindicator tourism infrastructure was rated with 0.25 because apart from footpaths there is no other tourism infrastructure. Subindicator hostelry service was evaluated with 0.5 , and restaurant service with 0.25 because of the tourist village "Čardak" which is located at a distance slightly less than $15 \mathrm{~km}$.

Adding up the grades for all of the 15 subindicators within the group of additional values, it can be concluded that the total grade for this group of values is 3.25 .

Adding up the grades for groups of main and additional values, the final grade of geosite is obtained, which in this case amounts 11.5. The overall grade puts the Dumača loess plateau in the $Z_{31}$ cell (Table 2, Figure 3). Each of the proposed geosites was evaluated according to the same principle.

Table 2 shows the values of each of the proposed geosites, as well as their placement in certain fields of 
Table 2. Classification of the proposed geosites in certain fields based on GAM model

\begin{tabular}{|l|c|c|c|c|}
\hline \multirow{2}{*}{$\begin{array}{l}\text { Propsed } \\
\text { geosites }\end{array}$} & \multicolumn{4}{|c|}{ Values } \\
\cline { 2 - 5 } & $\begin{array}{c}\text { Main } \\
\text { VSE+VSA+VPr }\end{array}$ & $\begin{array}{c}\text { Additional } \\
\text { VFn+VTr }\end{array}$ & Total & Field \\
\hline $\mathrm{GS}_{1}$ & $2+3+3.25$ & $2.25+1$ & 11.5 & $\mathrm{Z} 31$ \\
\hline $\mathrm{GS}_{2}$ & $1.5+2.5+2.75$ & $2.25+0.75$ & 9.75 & $\mathrm{Z} 21$ \\
\hline $\mathrm{GS}_{3}$ & $2+3+2.5$ & $2.25+1.5$ & 11.25 & $\mathrm{Z} 21$ \\
\hline $\mathrm{GS}_{4}$ & $2.75+2.75+2.75$ & $2.5+1$ & 11.75 & $\mathrm{Z} 31$ \\
\hline $\mathrm{GS}_{5}$ & $2+2.75+3$ & $2.25+2.5$ & 12.5 & $\mathrm{Z} 21$ \\
\hline $\mathrm{GS}_{6}$ & $1.75+3+3$ & $2.75+3$ & 13.5 & $\mathrm{Z} 22$ \\
\hline
\end{tabular}

GAM matrix. As it can be noted acording to overall grades, three out of six proposed geosites according to their grades belong to the field Z21. This means that they have a moderate level of main values and low level of additional ones. The reason for the low level of additional values is that in this area tourism is poorly developed, so tourism infrastructure and organization of tourism are missing. Two out of six proposed sites are ranked in the field $Z_{31}$, i.e. characterized by high level of main values and low level of additional values. In the field $Z_{22}$, which includes medium level of main and medium level of additional values only one proposed geosite was ranked.

It can be concluded that the main values for all proposed geosites are of a medium and high level, owing to their geological, geomorphological, interpretive and other values. The group of main values includes: rarity, representativeness, level of protection, vulnerability, environmental fitting of sites etc. As the nature of this area is largely preserved, and the entire area is characterized by rich geodiversity, main values of geosites were rated as medium and high. On the other hand, additional values for all proposed geosites, except one (GS6 - Labudovo okno), are low due to the poor organization of tourism, as well as poorly developed infrastructure. The group of additional values includes: accessibility, vicinity of emissive centers, vicinity of important road network, interpretative panels, tour guide service etc. Tourism of this area is generally poorly developed, and it was expected that the group of additional values for the proposed geosites will be evaluated as low. An exception is geosite Labudovo okno (GS6) which was declared as a Ramsar site. Protection of this area contributed to partially establishment of tourism infrastructure. At the site there is an information board, viewpoint, and in the immediate vicinity there are several significant anthropogenic values. Therefore, in the evaluation process this site was graded with higher score for additional (functional and touristic) values, and the overall rating of this site is higher than the rating of other proposed sites.

\section{Conclusion}

Due to the complex geological structure and geomorphological processes that took place in this area, during the Earth's history, Bela Crkva municipality has a high concentration of geodiversity, which provides good opportunities for the geotourism development. On the territory of the Municipality there are numerous natural resources, and some of them are protected. Protected areas are: Dumača loess plateau which is part of Special Nature Reserve "Deliblato Sands",

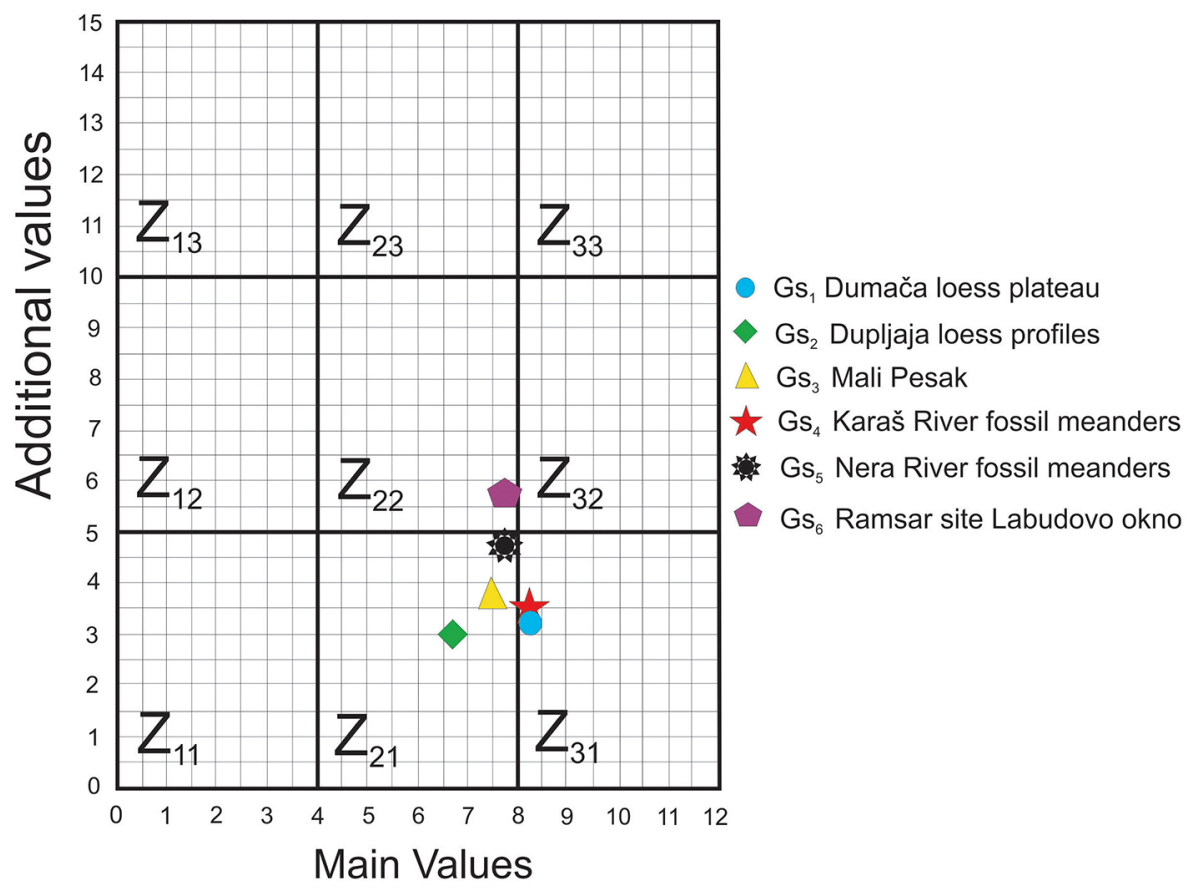

Figure 4. Classification of the proposed geosites in certain fields based on GAM model 
Labudovo okno which is protected as a Ramsar site, and the protection process of the Landscape of exceptional features "Karaš-Nera" is currently in progress. Furthermore, this area also has a number of anthropogenic values eg. important archaeological sites, which makes the tourist offer of this area very complex. Despite its values and extremely attractive motifs the entire area is still largely unexplored and unknown to the general public. There is a small number of scientific papers that deal with geological heritage of this area. Evaluation of proposed geosites lead to the conclusion that they possess a high level of main values thus they are favorable to geotourism development. However, these sites are characterized by a low level of additional values because the infrastructure and implementation of tourism are poor. In order to activate this area for touristic purpose, the adoption of the Strategy of tourism development, as a basis of planning and integrated tourism development is essential. In order to advance the current condition, construction of tourism infrastructure, adequate promotion and improvement of professional staff in the field of tourism are necessary.

\section{References}

Boškov, J. 2014a. Tourist presentation of the geoheritage in Bela Crkva municipality. Graduate thesis. University of Novi Sad, Department of Geography, Tourism and Hotel Management, Novi Sad, 90 pp. (in Serbian)

Boškov, J. 2014b. Geoheritage of Bela Crkva municipality. Citizens Association Aurora, Bela Crkva, 91 pp. (in Serbian)

Bukurov, B. 1954. Geomorphological opportunities of Banat Danube region. Collection of papers $8,55-88$. (in Serbian)

Đurović, P., Mijović, D. 2006. Geoheritage of Serbiarepresentative of its overall geodiversity. Collection of papers 54, 5-18. (in Serbian with English summary)

Gray, M. 2004. Geodiversity: Valuing and Conserving Abiotic Nature. John Wiley \& Sons, Ltd, Chichester, $434 \mathrm{pp}$.

Hose T. A. 2005. Geotourism and Interpretation. Geotourism, 221-241.

Hose T.A. 2012. 3G's for modern geotourism. Geoheritage 4, 7-24.

Hrnjak, I., Vasiljević, Dj. A., Marković, S. B., Vujičić, M. D., Lukić, T., Gavrilov, M. B., Basarin, B., Kotrla, S. 2013. Application of preliminary geosite assessment model (GAM): The case of the Deliblato Sands. Collection of papers 2, 59-65. (In Serbian with English summary)

Lukić, T. 2010. Palaeoclimatic and palaeoecological characteristics of loessprofile Zagajička hills. Mas- ter thesis. University of Novi Sad, Department of Geography, Tourism and Hotel Management, Novi Sad, 53 pp. (in Serbian)

Lukić, T., Hrnjak, I., Marković, S. B., Vasiljević, Dj. A., Vujičić, M. D., Basarin, B., Gavrilov, M. B., Jovanović, M., Pavić, D. 2013. Zagajica hills as an archive of paleoclimatic and paleoecological characteristics and possibilities for geoconservation. Nature Conservation 63, 59-71. (In Serbian with English summary)

Pereira, P., Pereira, D., Caetano Alves, M. I. 2007. Geomorphosite assessment in Montesinho Natural Park (Portugal). Geographica Helvetica 62, 159-168.

Petrović, M. D., Vasiljević, Dj. A., Vujičić, M. D., Hose, T. A., Marković, S. B., Lukić, T. 2013. Global Geopark and Candidate - Comparative analysis of Papuk Mountain Geopark (Croatia) and Fruška Gora Mountain (Serbia) by using GAM Model. Carpathian Journal of Earth and Environmental Sciences 8-1, 105-116.

Pralong, J. P. 2005. A method for assessing the tourist potential and use of geomorphological sites. Géomorphologie: Relief, processus, environnement 3, 189-196.

Reynard, E., Fontana, G., Kozlik, L., Scapozza, C. 2007: A method for assessing "scientific" and "additional values" of geomorphosites. Geographica Helvetica 62-3. Basel.

Sharples, C. 2002. Concepts and Principles of Geoconversation. Parks \& Wildlife Service, Tasmania, 79 pp.

Tomić, N. 2011. The potential of Lazar Canyon (Serbia) as a geotourism destination: inventory and evaluation. Geographica Pannonica 15-3, 103-112.

Tomić, N., Božić S. 2014. A modified geosite assessment model (M-GAM) and its application on the Lazar Canyon area (Serbia). International Journal of Environmental Research 8-4, 1041-1052.

Vasiljević, Dj. A., Marković, S. B., Hose, T. A., Ding, Z., Guo, Z., Liu, X., Smalley, I., Lukić, T., Vujičić, M. D. 2014. Loess-palaeosol sequences in China and Europe: Common values and geoconservation issues. Catena 117,108-118.

Vujičić, M.D., Vasiljević, Dj. A., Marković, S. B., Hose, T. A., Lukić, T., Hadžić, O. 2011.Preliminary Geosite Assessment Model (GAM) and its Application on Fruška Gora Mountain, Potential Geotourism Destination of Serbia. Acta geographica Slovenica 51-2, 361-377.

Provincial Institute for Nature Conservation. 2011. The Landscape of exceptional features "KarašNera", The proposal for protection as a protected area of II category. Novi Sad, 119 pp. (in Serbian)

$$
\propto
$$

www.geoconservation.com

www.googleearth.com

www.ramsar.org. 